\title{
Phytochemical screening and hypoglycaemic activity of Lasianthera africana Beauv. (Aquifoliales: Stemonuraceae) leaf extract on diabetic rats
}

\section{Norah Godwin Ekanem ${ }^{1,3,}$, Herbert Orji Chidi Mbagwu ${ }^{2}$ and Gamaliel Ibiama Harry ${ }^{1}$}

${ }^{1}$ Department of Crop Science. Faculty of Agriculture. University of Uyo. P.M.B.1017, Uyo, Nigeria.*Email: norahgodwin@uniuyo.edu.ng.

2Department of Pharmacology and Toxicology, Faculty of Pharmacy, University of Uyo, P.M.B. 1017, Uyo, Nigeria.

${ }^{3}$ Plant Genetics Resources and Cell and Tissue Research Laboratory, Department of Genetics and Biotechnology, University of Calabar, Calabar, Nigeria.

\begin{abstract}
Lasianthera africana Beauv. (Aquifoliales: Stemonuraceae) is a native leafy vegetable used in traditional medicine for control and management of problems associated with complications of diabetes mellitus. The study was aimed to evaluate the phytochemical and hypoglycaemic properties for effective control of diabetes. Phytochemical analyses were conducted using standard methods. The rats were divided into four groups of six rats each of which Group 1 received distilled water $(1 \mathrm{~mL})$; Group 2 received aqueous extract (doses of $500 \mathrm{mg} / \mathrm{kg}, 1,000 \mathrm{mg} / \mathrm{kg}$ and $1,500 \mathrm{mg} / \mathrm{kg}$ ); Group 3 received ethanolic extract (doses of $500 \mathrm{mg} / \mathrm{kg}, 1,000 \mathrm{mg} / \mathrm{kg}$ and $1,500 \mathrm{mg} / \mathrm{kg}$ ); Group 4 received synthetic drug (dose of $10 \mathrm{mg} / \mathrm{kg}$ ) for seven consecutive days. The phytochemical showed the presence of alkaloids, glycosides, saponins, tannins, phlobatannins, flavonoid and terpenes. Hypoglycaemic studies of $1,000 \mathrm{mg} / \mathrm{kg}$ body weight of the ethanolic extract administered intraperitoneally significantly reduced the blood sugar level $(\mathrm{p}<0.05)$ from $239.71 \pm 4.26 \mathrm{mg} / \mathrm{dL}$ (fasting hour) to $51.42 \pm 2.19 \mathrm{mg} / \mathrm{dL}$ within $4 \mathrm{~h}$ post administration. The aqueous extract also significantly lowered the blood sugar from $230.29 \pm 5.54 \mathrm{mg} / \mathrm{dL}$ to $88.57 \pm 4.88 \mathrm{mg} / \mathrm{dL}$ within $3 \mathrm{~h}$. The percentage decrease in blood sugar level of ethanolic extract at $1,000 \mathrm{mg} / \mathrm{kg}$ was more significant $(\mathrm{p}<0.05)$ than glibenclamide. Acute toxicity showed that $L$. africana was non toxic because $5,000 \mathrm{mg}$ extract $/ \mathrm{kg}$ body weight did not produce visible toxic sign or mortality within $24 \mathrm{~h}$. The study has shown that $L$. africana leaf possesses some useful medicinal potential for therapeutic purposes and that the hypoglycaemic activity of the leaf could be utilized by diabetic patients as supplement. This may contribute greatly to the management of their health conditions. The evaluation of hypoglycaemic activity in this study validates the claims that the plant leaf is useful in controlling and management of diabetes mellitus.
\end{abstract}

Keywords: Lasianthera africana; Phytochemicals; Hypoglycaemic activity; Diabetes mellitus; Intraperitoneal.
Received

November 11, 2016

Accepted

December 27, 2016

Released

December 31, 2016

Open Acess Full Text Article

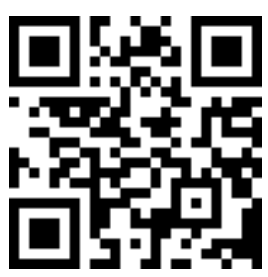

ORCID

(ㄹ) 0000-0003-4615-2512 Norah Godwin Ekanem () 0000-0003-1159-9779

Herbert Orji Chidi Mbagwu

() 0000-0002-5664-0870 Gamaliel Ibiama Harry 


\section{Introduction}

Crop plants generally represent an extraordinary reservoir of novel molecules. However, hundreds of thousands of metabolites may be present in medicinal crop plant. There is currently a resurgence of interest in the use of vegetables as a possible source of new lead compounds for therapeutic screening (Hostettma et al., 1997). Lasianthera africana Beauv. (Aquifoliales: Stemonuraceae) is a vegetable crop which has promising potentials for curative uses. It is commonly known as "editan" in Efik and Ibibio communities of Akwa Ibom and Cross River States. It is monospecific genus located in South Eastern Nigeria and extending towards Camerouns (Bassey et al., 2004). They are used in traditional concoction for the treatment of constipation, stomach aches/ulcer and prevention of miscarriage in pregnant women (Sofowora, 1993). Folklore information revealed that the decoction of the plant is used as a remedy for internal heat as well as antihelmintic agent. Chatterjee (1963) reported that bitter principles from plants were associated with management and control of diabetes mellitus. Prevalence of diabetes in some countries has risen up to $1 \%$ to $2 \%$ of the population with African countries on the increase (Barnett, 1991). It is estimated that about 140 million people worldwide are affected by diabetes and it is quite shocking to note that in our teeming population almost one million Nigerians are suffering from this traumatic disease (Ike, 2001).

Despite considerable progress in the management of diabetes mellitus by conventional synthetic drugs, the search for natural anti-diabetic plant for the control of diabetes is crucial. This calls for the evaluation of the therapeutic potential of $L$. africana leaf in the control and management of diabetes mellitus using experimentally induced diabetic rats.

\section{Materials and methods}

\section{Plant material}

L. africana leaves were collected from Essien Udim Local Government Area of Akwa Ibom State, Nigeria.

\section{Extraction and analysis}

$600 \mathrm{~g}$ each of ground air-dried leaf sample were extracted with $70 \%$ of ethanol at room temperature while aqueous extraction was carried out with the cold extraction method. The extracts were concentrated under pressure to yield $46.0 \mathrm{~g}$ and $28.0 \mathrm{~g}$ ethanol and aqueous extract, respectively.

\section{Phytochemical analysis}

Phytochemical screening of the leaf was conducted on the two extracts according to the methods described by Trease and Evans (2002). All experimental procedures for phytochemical screening were replicated 3 times to establish the reproducibility of the extract.

\section{Experimental animals}

Twenty-four (24) male albino rats of body weight range of 120-200 g were purchased from Animal Unit of The Department of Pharmacology and Toxicology, University of Uyo, Uyo, Nigeria. The rats had access to pellets (product of Feeds Grower Nigeria Ltd.) and drinking water before they were fasted overnight.

\section{Diabetes induction}

The animals were fed with standard pellet and after $12 \mathrm{~h}$ fasting overnight, the animals were made to be diabetic by a single dose of alloxan (150 mg/kg) administered as $5 \% \mathrm{w} / \mathrm{v}$ in distilled water injected by intraperitoneal (i.p) route. Diabetes developed after $72 \mathrm{~h}$ and confirmation was carried out by testing glucosuria using indicator sticks (Bayer Diagnostics Basingstoke, UK). Rats with fasting blood sugar at $200 \mathrm{mg} / \mathrm{dL}$ and above 
were considered diabetic (Gidado et al., 2005).

\section{Hypoglycaemic evaluation}

The 24 experimental rats were divided into four groups with six animals per group. Group 1 served as normal control and received $(1 \mathrm{~mL})$ distilled water; Group 2 received $500 \mathrm{mg} / \mathrm{kg}, 1,000 \mathrm{mg} / \mathrm{kg}$ and $1,500 \mathrm{mg} / \mathrm{kg}$ of ethanolic extract and Group 3 received $500 \mathrm{mg} / \mathrm{kg}, 1,000 \mathrm{mg} / \mathrm{kg}$, $1,500 \mathrm{mg} / \mathrm{kg}$ of aqueous extract, respectively. Group 4 received $10 \mathrm{mg} / \mathrm{kg}$ of reference control drug Daonil (glibenclamide) (Resmi et al., 2001; Ghosh et al. 2004). Blood samples were collected between and after treatments.

\section{Toxicity}

The $\mathrm{LD}_{50}$ of the extract was done on the rats by oral and intraperitoneal (i.p) route using the method of Dietrich (1983). In the first phase, 24 male albino rats randomly divided into four groups of six rats per group were given 500, 1,000, 1,500 $\mathrm{mg}$ extract/kg body weight orally (via a cannula), respectively. The rats were observed for signs of adverse effects and death for $24 \mathrm{~h}$ and then weighed daily for 14 days. In the second phase of the study, the procedure was repeated using six rats randomly divided into four groups each given 500, 1,000, 1,500 mg extract/kg body weight intraperitoneally. The rats were also observed for signs of toxicity, mortality and weighed for 14 days.

\section{Statistical analysis}

Statistical analysis were performed by ANOVA, using SPSS (Naggar, 2005).

\section{Results and discussion}

Phytochemical screening revealed the presence of alkaloids, philobatannis, flavonoids, glycosides, terpenes, tannins and saponnins (Table 1). This shows that Lasianthera africana contains important class of bioactive substances, frequently employed as starting material for the synthesis of some useful drugs. The

Table 1. Qualitative phytochemical screening result of aqueous and ethanolic leaf extracts of L. africana.

\begin{tabular}{|c|c|c|}
\hline \multirow{2}{*}{ Tests } & \multicolumn{2}{|c|}{ Conclusion } \\
\hline & Aqueous extract & Ethanol extract \\
\hline $\begin{array}{l}\text { Alkaloids } \\
\text { (i) Dragendorff's reagent } \\
\text { (ii) Mayer's reagent } \\
\text { (iii) Wagner's reagent }\end{array}$ & $\begin{array}{c}+++ \\
++ \\
+\end{array}$ & $\begin{array}{l}+++ \\
+++ \\
++\end{array}$ \\
\hline $\begin{array}{l}\text { Philobatannins } \\
\text { Hydrochloric Acid }\end{array}$ & + & ++ \\
\hline $\begin{array}{l}\text { Flavonoids } \\
\text { Magnesium Metal }\end{array}$ & ++ & +++ \\
\hline $\begin{array}{l}\text { Anthrquinones } \\
\text { Bomtrager }\end{array}$ & - & - \\
\hline $\begin{array}{l}\text { Glyosides } \\
\text { (i) Salkowski } \\
\text { (ii) Keller Killiani } \\
\text { (iii) Sodium Picrate }\end{array}$ & $\begin{array}{c}++ \\
++ \\
+\end{array}$ & $\begin{array}{c}+++ \\
+++ \\
+\end{array}$ \\
\hline $\begin{array}{l}\text { Terpenes } \\
\text { Lieberman's }\end{array}$ & + & ++ \\
\hline $\begin{array}{l}\text { Tannins } \\
\text { (i)Ferric Chloride } \\
\text { (ii)Bromine Water }\end{array}$ & $\begin{array}{l}+++ \\
+++\end{array}$ & $\begin{array}{l}+++ \\
+++\end{array}$ \\
\hline $\begin{array}{l}\text { Saponins } \\
\text { (i) Frothing } \\
\text { (ii) Fehling Solution } \\
\text { (iii) Sodium bicarbonate }\end{array}$ & $\begin{array}{l}1 \\
+++ \\
+++ \\
+++\end{array}$ & $\begin{array}{l}+++ \\
+++ \\
+++\end{array}$ \\
\hline
\end{tabular}

$+++=$ Strongly present $;++=$ moderately present $;+=$ trace; $-=$ absent. 
hypoglycaemic studies as shown with the ethanolic and aqueous extracts of the plant significantly lowered blood sugar levels $(\mathrm{p}<0.05)$ which compared favourably with the synthetic reference drug. This study implies that $L$. africana leaf possesses adequate anti-diabetic properties which may be useful for diabetic patients in the management and control of this complex disorder (Table 2 and Figure 1). This study corroborates with the findings of Delfan et al. (2014) who reported that anti-diabetic herbs have phytochemicals that can inhibit facilitated diffusion and glucose uptake through active transportation. The decrease in blood sugar could be beneficial in preventing diabetic complications as well as improving lipid metabolism in diabetic patients (Cho et al., 2002). Toxicity results showed that the leaf is non-toxic and confirmed its safety for consumption (Etukudo, 2003) (see Table 3 and 4).

Table 2. Comparative analysis of blood glucose levels (mg/dL) of alloxan-induced diabetic rats treated with different concentrations of aqueous and ethanolic L. african leaf extracts.

\begin{tabular}{|c|c|c|c|c|c|c|c|c|c|c|}
\hline \multirow[b]{2}{*}{ Treatment } & & \multirow{2}{*}{$\begin{array}{l}\text { Blood } \\
\text { glucose level } \\
\text { before } \\
\text { alloxan }\end{array}$} & \multirow{2}{*}{$\begin{array}{l}\text { Blood } \\
\text { glucose level } \\
\text { after alloxan } \\
\text { induction }\end{array}$} & \multicolumn{7}{|c|}{ Blood glucose level after treatment with the leaf extracts } \\
\hline & & & & $1 \mathrm{~h}$ & $2 \mathrm{~h}$ & $3 \mathrm{~h}$ & $4 \mathrm{~h}$ & $5 \mathrm{~h}$ & $6 \mathrm{~h}$ & $7 \mathrm{~h}$ \\
\hline $\begin{array}{l}\text { Diabetic control } \\
\text { (distilled water) } \\
(1 \mathrm{~mL})\end{array}$ & 1 & $62.67 \pm 3.48$ & $245.28 \pm 10.01$ & $253.57 \pm 9.44$ & $259.0 \pm 8.05$ & $261.46 \pm 7.92$ & $260.94 \pm 9.79$ & $261.37 \pm 8.00$ & $260.65 \pm 6.74$ & $261.35 \pm 7.96$ \\
\hline 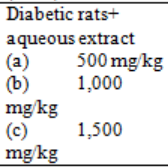 & 2 & $\begin{array}{l}59.67 \pm 3.18 \\
69.0 \pm 0.58 \\
65.57 \pm 2.85\end{array}$ & \begin{tabular}{l|}
$204.0 \pm 3.06$ \\
$230.28 \pm 5.54$ \\
$264.33 \pm 22.92$
\end{tabular} & $\begin{array}{l}201.0 \pm 2.65 \\
196.85 \pm 14.48 \\
163.67 \pm 8.76\end{array}$ & $\begin{array}{l}195.33 \pm 3.18 \\
150.71 \pm 14.94 \\
116.67 \pm 14.53\end{array}$ & $\begin{array}{l}188.33 \pm 2.60 \\
88.57 \pm 4.87 \\
104.67 \pm 13.48\end{array}$ & $\begin{array}{l}176.0 \pm 5.03 \\
111.71 \pm 4.06 \\
76.0 \pm 8.08\end{array}$ & $\begin{array}{l}179.24 \pm 4.08 \\
129.71 \pm 7.40 \\
74.56 \pm 15.4\end{array}$ & $\begin{array}{l}183.34 \pm 8.04 \\
144.85 \pm 7.22 \\
69.374 \pm 21.25\end{array}$ & $\begin{array}{l}189.05 \pm 5.14 \\
178.00 \pm 7.22 \\
64.81 \pm 14.6\end{array}$ \\
\hline 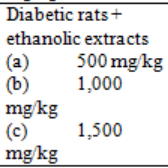 & 3 & $\begin{array}{l}57.33 \pm 1.86 \\
59.67 \pm 3.38 \\
51.33 \pm 3.76\end{array}$ & $\begin{array}{l}287.33 \pm 9.91 \\
239.71 \pm 4.25 \\
222.0 \pm 10.21\end{array}$ & $\begin{array}{l}250.33 \pm 4.70 \\
182.00 \pm 8.30 \\
167.0 \pm 12.34\end{array}$ & $\begin{array}{l}217.67 \pm 8.82 \\
147.57 \pm 7.30 \\
109.33 \pm 4.64\end{array}$ & $\begin{array}{l}187.67 \pm 2.33 \\
77.28 \pm 2.29 \\
86.67 \pm 3.18\end{array}$ & $\begin{array}{l}162.33 \pm 4.91 \\
51.42 \pm 2.19 \\
38.67 \pm 3.53\end{array}$ & $\begin{array}{l}165.55 \pm 7.63 \\
83.42 \pm 4.21 \\
36.42 \pm 10.24\end{array}$ & $\begin{array}{l}170.06 \pm 8.04 \\
121.85 \pm 5.06 \\
33.53 \pm 7.65\end{array}$ & $\begin{array}{l}177.46 \pm 10.36 \\
169.14 \pm 17.12 \\
28.26 \pm 16.36\end{array}$ \\
\hline $\begin{array}{l}\text { Diabetic + } \\
\text { glibenclamide } \\
(10 \mathrm{mg} / \mathrm{kg})\end{array}$ & 4 & $57.33 \pm 1.45$ & $246.0 \pm 7.11$ & $181.0 \pm 12.75$ & $129.0 \pm 11.36$ & $81.0 \pm 2.30$ & $101.42 \pm 3.05$ & $116.0 \pm 5.83$ & $128.0 \pm 10.06$ & $136.71 \pm 8.54$ \\
\hline
\end{tabular}

Values are expresssed as mean \pm SEM in 3 replicates; statistical significance $(p<0.05)$.

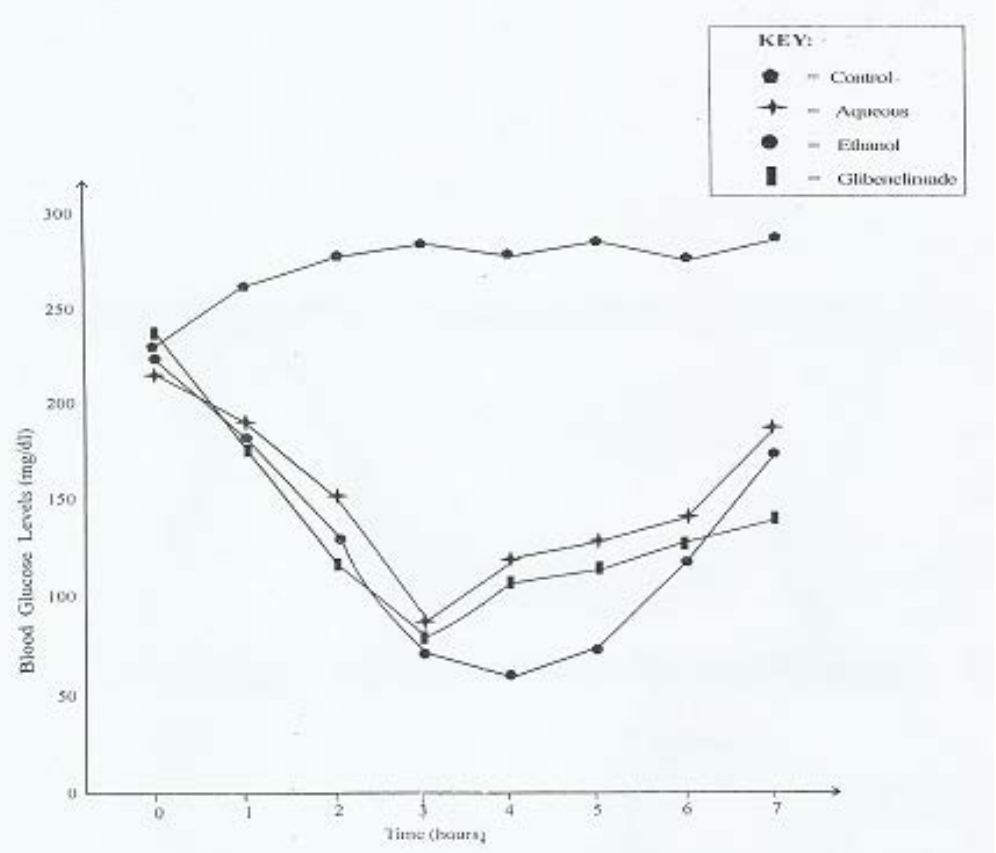

Figure 1. Effect of $1,000 \mathrm{mg} / \mathrm{kg}$ of aqueous and ethanol leaf extracts of $L$. africana on diabetic rats. 
Table 3. Toxicity test trials of ethanol extract on oral administration.

\begin{tabular}{lccc}
\hline $\begin{array}{l}\text { Dose } \\
(\mathbf{m g} / \mathbf{k g})\end{array}$ & Number of dead mice (in 24 h) & Percentage Death & Time range of death (h) \\
\hline 1,000 & $\mathrm{Nil}$ & $\mathrm{Nil}$ & $\mathrm{Nil}$ \\
2,000 & $\mathrm{Nil}$ & $\mathrm{Nil}$ & $\mathrm{Nil}$ \\
3,000 & $\mathrm{Nil}$ & $\mathrm{Nil}$ & Nil \\
4,000 & $\mathrm{Nil}$ & $\mathrm{Nil}$ & Nil \\
5,000 & $\mathrm{Nil}$ & $\mathrm{Nil}$ & Nil \\
\hline
\end{tabular}

Table 4. Toxicity test trials of ethanol extract after intraperitoneal administration of the extract.

\begin{tabular}{lccc}
\hline $\begin{array}{l}\text { Dose } \\
(\mathbf{m g} / \mathbf{k g})\end{array}$ & Number of dead mice (in $\mathbf{2 4} \mathbf{h})$ & Percentage death & Time range of death (h) \\
\hline 1,000 & Nil & Nil & Nil \\
2,000 & Nil & Nil & Nil \\
3,000 & Nil & Nil & Nil \\
4,000 & Nil & Nil & Nil \\
5,000 & Nil & Nil & Nil \\
\hline
\end{tabular}

\section{Conclusion}

The study has established for the first time, that Lasianthera africana leaf possesses hypoglycaemic and antihyperglycaecmic properties and could serve as anti-diabetic regimen. It also validates the claims of the plant's use as an antidiabetic supplement. It is necessary for researchers to find out the active substances responsible for hypoglycaemic activity, so that it would be possible to produce drugs which are useful in management and control of diabetes.

\section{Acknowledgement}

The authors appreciate the efforts of Messrs Bala Danladi and Malachy Nsikan for all the technical and laboratory assistance. We acknowledge the contributions of late Dr. (Sir) C.S. Odoemena, late Mr. E. B. Oforah and Prof. Kingsley Akpabio for their encouragement.

\section{Conflicts of interest}

Authors declare that they have no conflict of interests.

\section{References}

Barnett, A. H. Diabetes mellitus in the tropics. Trans. R. Soc. Trop. Med. Hyg., v. 85, p. 324335, 1991.

Bassey, M. E.; Etuk, U. I.; Ekpo, J. U. Morphological diversity in the macrophyte genus Lasianthera (Icacinaceae) and the tanonomic implications. Liv. Sys. Sus. Dev., v. 2, p. 1-5, 2004.

Cho S. Y.; Park, J. P.; Park, E. M.; Choi, M. S.; Lee, M. Y.; Jeon, S. M.; Jang, M. K.; Kim, M. J.; Park, Y. B. Alternation of hepatic antioxidant enzyme activities and lipid profile in streptozotocin-induced diabetic rats by supplementation of dandelion water extract. Clin. Chem. Acta, v. 317, p. 109-117, 2002.

Delfan, B.; Saki, K.; Bahmani, M.; Rangsaz, N.; Delfan, M.; Mohseni, N.; Shirzad, H.; Babaein, Z. A study of anti-diabetic and antihypertension herbs used in Lorestan Province, Iran. J. HerbMed. Pharmacol., v. 3, no. 2, p. 71-76, 2014. Available from: <http://www.herbmedpharmacol.com/PDF/JHP3-71.pdf>. Accessed on: Oct. 15, 2016.

Dietrich, L. A new approach to practical acute toxicity testing. Arch. Toxicol., v. 54, p. 275287, 1983.

Etukudo, I. Ethnobotany: conventional and traditional uses of plants. Uyo: The Verdict Press, 2003. 
Ghosh, R.; Sharatchandra, K. H.; Rita S.; Thokchom, S. I. Hypoglycaemic activity of Ficus hispida bark in normal and diabetic albino rats. Indian J. Pharmacol., v. 36, no. 4, p. 222225, 2004.

Gidada, A.; Ameh, D. A.; Atawodi, S. E. Effect of Naucla latifolia leaves aqueous extracts on blood glucose levels of normal and alloxaninduced diabetic rats. African J. Biotech., v. 4, no. 1, p. 91-93, 2005.

Hostettman K.; Wolfender, J. I.; Rodrigues, S. Rapid detection and subsequent isolation of bioactive constituents of crude extract. Planta Medica I, v. 63, no. 2, p. 2-10, 1997.

Ike, V. One million Nigeria diabetes. North Director, Vanguard Profile. South-East-News. 19th November, 2001. p. 22.
Naggar, E. M. B.; Bartosikova, L.; Zemlicka, M.; Svajdlenka, E.; Rabiskova, M.; Strnedova, V.; Necas, J. Antidiabetic effect of Cleome droserifolia aerial parts: lipid peroxidation induced oxidative stress in diabetic rat. Acta Vet. Brno., v. 74, p. 347-352, 2005.

Resmi, C. R.; Fathima, A.; Sinilal, B.; Latha, M. S. Anti-diabetic effect of herbal drug in alloxan-diabetic rats. Indian Drugs, v. 38, no. 6, p. 319-322, 2001.

Sofowora, A. Medicinal plants and traditional medicine in Africa. Ibadan, Nigeria: Spectrum Books, 1993.

Trease, G. E.; Evans, W. C. A textbook of Pharmacognosy. 15. ed. London: Bailliere Tindall, 2002. p. 1150-1159.

License information: This is an open-access article distributed under the terms of the Creative Commons Attribution License, which permits unrestricted use, distribution, and reproduction in any medium, provided the original work is properly cited. 